Portland State University

PDXScholar

\title{
Faculty and Graduate Peer Mentors Online Experiences in Teaching and Mentoring
}

Staci B. Martin

Portland State University, mar24@pdx.edu

Meredith Esther Michaud

Portland State University, meredithmichaud@hotmail.com

Christian D. Logerstedt

Portland State University

Follow this and additional works at: https://pdxscholar.library.pdx.edu/socwork_fac

Part of the Social Work Commons

Let us know how access to this document benefits you.

Citation Details

Martin, S. B., Michaud, M. E., \& Logerstedt, C. D. (2019) Faculty and graduate peer mentors online experiences in teaching and mentoring. Journal of General Education: A Curricular Commons of the Humanities and Sciences, 67(3-4), 79-96.

This Article is brought to you for free and open access. It has been accepted for inclusion in School of Social Work Faculty Publications and Presentations by an authorized administrator of PDXScholar. Please contact us if we can make this document more accessible: pdxscholar@pdx.edu. 


\title{
Faculty and Graduate Peer Mentors Online Experiences in Teaching and Mentoring
}

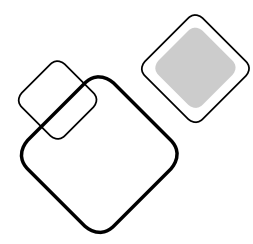

\author{
STACI B. MARTIN, MEREDITH E. MICHAUD, AND CHRISTIAN D. LOGERSTEDT
}

\begin{abstract}
For both Sophomore Inquiry (SINQ) faculty and graduate peer mentors, online education offers a chance to explore pedagogical approaches and adapt to new or different technology solutions to communicate with students. The purpose of this article is to explore how online SINQ faculty and graduate peer mentors instruct, build relationships, and interrupt oppressive situations while delivering an online course. The research examined how SINQ faculty and graduate peer mentors' pedagogy and practices evolved when translated from brick and mortar classrooms to online contexts. Semi-structured interviews were conducted. Transcripts were coded and thematic analysis was done. Critical hope was used as the conceptual framework. Four themes were identified: online instruction, SINQ faculty and graduate peer mentor relationships, interrupting oppressive language and behaviors, and online strategies. The last theme is presented as a table of participants' online strategies that highlights the effective practices in creating, nurturing, and sustaining equitable online learning environments.
\end{abstract}

\author{
KEYWORDS | faculty \\ and graduate peer \\ mentor relationships, \\ graduate peer \\ mentoring, online \\ instruction, critical \\ hope
}

The structure of University Studies, Portland State University's general education program, with its interdisciplinary thematic approach, its four goals, and its incorporation of undergraduate and graduate peer mentors into online courses, presents unique experiences to those involved in online instruction. For both Sophomore Inquiry (SINQ) faculty and graduate peer mentors, online education offers a chance to explore pedagogical approaches and adapt to new or different technology solutions to communicate with students. 
Through semi-structured interviews with Portland State University Studies SINQ faculty and graduate peer mentors, we offer examples of the possibilities, the challenges, and the realities of being a SINQ faculty member or graduate peer mentor in an online context. The purpose of our article was to explore how online SINQ faculty and graduate peer mentors instruct, build relationships, and interrupt oppressive situations while delivering an online course.

\section{Background}

Most literature on peer mentoring describes mentoring within a variety of contexts such as workplace mentoring (Washington \& Cox, 2016), mentoring in higher education (Collier, 2017; Crisp \& Cruz, 2009; Budge, 2006), and youth mentoring (Albright, Hurd, \& Hussain, 2017; DuBois, 2014). There is limited research on peer mentoring programs (Budge, 2006). There appears to be more limited research with regard to how faculty members work with either undergraduate and graduate peer mentors while delivering an online course.

Mentoring definitions vary. Mentors can be defined as being paired with a more experienced person to an inexperienced person in a specific field (e.g., a tenured faculty member paired with a junior faculty member, experienced teacher with a first-year teacher). According to Colvin and Ashman (2010), in the higher education context, peer mentors' are more experienced students that are supporting less experienced students to strengthen academic performance, navigate their first years of university, and provide advice and resources.

Portland State's undergraduate and graduate peer mentor program supports Freshman Inquiry (FRINQ) and SINQ courses and faculty. The role of the mentor is multifaceted, with mentors serving as role models in several aspects of academic life. Peer Mentors are "trained in writing and editing procedures, critical reading methodology, small group facilitation and cooperative group work, basic library research, and campus resource brokering" (University Studies, 2017, p. 10). This model of student peer mentors is a building block to support students in the transition to their Junior Cluster and Capstone courses. University Studies courses are anchored in building authentic relationships, redistributing power, and working within a social justice model, and thus support a critical hope framework.

\section{Critical Hope: Conceptual Framework}

We chose to use a critical hope conceptual framework because it posits a practice of teaching that applies a critical inquiry lens for "co-creat [ing] spaces of hope for both the teacher and learner to recognize their own agency and ability to question the status quo, as they are strengthening their critical 
thinking skills" (Martin et al., 2018, p. 142). Critical hope is a construct of pedagogy of hope (Freire, 1994) and stems from critical theory in which there is a link between understanding of self and the self in relation to society.

Often when applying a critical hope framework, we bring into the context of history, social, and political influences that impact our student's lives. By using this conceptual framework, SINQ faculty and graduate peer mentors attempt to interrogate systems of inequity and the distribution of power through their instruction, curriculum, and group discussions. As both the SINQ faculty member, graduate peer mentor, and student begin to question systems of inequity, it is their job to find ways to create change either within themselves and/or bring action to the particular problem. Too often critical theory just interrogates the problem, whereas critical hope is hope with action.

\section{Methodology}

Our qualitative research consisted of semi-structured interviews (Brinkmann, 2014; Fylan, 2005) and was approved by an Internal Review Board. SINQ faculty and online graduate peer mentors self-selected after receiving an invitation through email and were given an informed consent of their rights that outlined the objectives and limitations of the research. We conducted 20- to 30- minute semi-structured interviews with all nine participants.

In the semi-structured interviews, we started with the protocol of interview questions and used probing techniques to encourage participants to expand on their responses. We designed an interview protocol which included main questions, additional questions, and clarifying questions. Our main question was "In what ways do online faculty and online graduate peer mentors create strategies for communication, cultivating connections, technology solutions, and logistics in University Studies online courses?" Interviews were conducted by one or two interviewers from our research team and were audio-recorded with the permission of participants. We coded the interviews following Saldaña's (2013) Codes to Theory model and followed up with a member check-in three months later.

\section{Participants}

Participants were recruited within University Studies. We recruited five SINQ faculty and four graduate peer mentors. Although, the Graduate Peer Program does have undergraduate peer mentors for their FRINQ courses, they did not self-select. In addition, we interviewed four other faculty that taught senior capstones. We hope to include their data in a future paper on online learning strategies. However, due to the themes we saw in the overall data, the 
constraints in article length, and the desire to have a focused and coherent paper, we made the decision to focus on SINQ faculty and graduate peer mentors in this paper.

Participants were asked to self-identify some of their demographic characteristics. Out of our nine participants, seven self-identified as female and two self-identified as male. Two of the participants self-identified as gay or queer, while the remaining seven self-identified as straight or heterosexual. Five participants self-identified as White, and the remaining four participants gave other responses. With regard to age, one participant was in the 18 to 24 age range; three were 25-34; four were 35-44; and one was 45-54.

Also, the four mentors did not mentor for the any of the five SINQ faculty. Although, it might have been interesting to pair SINQ faculty with their current mentors, we felt we may put both them in a space they could not speak truthfully about particular topics.

\section{Analysis}

After the interviews were complete they were transcribed and coded. Each transcript was reviewed and coded by descriptive coding. Two different researchers coded the same transcript in order to achieve inter-rater reliability (James, Demaree, \& Wolf, 1984). When there was variance in the coding, the researchers that coded the particular transcript had a conference to establish consensus on a single code. See Figure 1 that demonstrates our coding.

Then, a master code list was created. Finally, using the codes to theory model (Saldaña, 2013), patterns were determined in the coding, then categories and themes, which are discussed in the results section. We found four themes which were online instruction, SINQ faculty and graduate peer mentor relationships, interrupting oppressive language and behaviors, and participants' online strategies.

By applying a qualitative methodology, we attempted to analyze "concrete experiences of [our participant's] daily lives - close up angle for witnessing social action," as well as to observe transformative learning in an online context (Saldaña, 2015, p. 85). We also chose to use verbatim quotes that followed the determined themes. The verbatim quotes are grounded in the following constructs outlined by Corden and Sainsbury (2006) "as the matter of enquiry; as evidence; as explanation; as illustration; to deepen understanding; to give participants a voice, and to enhance readability" (p. 11). We chose to go this route because too often words are paraphrased and misinterpreted by the researcher. Thus, we wanted the words of the participant to stand on their own. Also, in place of participant names, we use pseudonyms that give a nod to Portland neighborhoods. To avoid gendered pronouns, all participants have plural pronouns. 


\section{Results}

Our first theme is online instruction. This theme explores how pedagogy and instruction may shift in an online context. Our second theme addresses SINQ faculty and graduate peer mentor relationships. The third theme describes situations and experiences of interrupting oppression in an online context. Our last theme, which is shared in the discussion section, describes ways our participants imparted a rich array of effective practices in teaching and mentoring online.

\section{SINQ Faculty and Graduate Peer Mentors Online Instruction}

Both online SINQ faculty and graduate peer mentors have faced challenges in translating the synchronous classroom into an online setting. For example, a SINQ faculty member remarked,

The big thing I change when I'm moving a face to face class online, I'm asking myself how do I take the activities ... with the students face-to-face and change it. So that I'm getting similar outcomes or similar knowledge with the online students. (Pearl, July 22, 2018)

One graduate peer mentor explained an asynchronous classroom like this, "I think it's easier to draw out those ideas from people, but it can be hard or difficult to really, you know, talk with that person because [they are] behind a keyboard (Portsmouth, June, 13, 2018). The graduate peer mentor continued to offer an example of how to take an asynchronous classroom and move it to a synchronous classroom virtually, when Portsmouth said,

I have an online example actually from this last term where we do this thing called synchronous activities where I make a Google doc or Google web form [with] five days of the week [and] they sign on to Google Hangouts, or I use some in-person, as well. It's just time to sit for an hour uninterrupted. We talk about a topic.... We have 6-7 of them in a room and all run our ideas by each other or online, too ... the feedback I've gotten was that it was really great to have that time just to, like, see some people's faces instead of to just reply to discussion posts. (June, 13, 2018)

Another SINQ faculty member's strategy to work within asynchronous classrooms was to consolidate their papers into a large project. Pearl said,

[What] I ended up doing was thinking of my courses as working on one project for the whole term and scaffolding the course to work on that 
one project. Early in my career, I was teaching composition and poetry writing, and so we would do like three or four different papers or three or four different projects, and then do a portfolio. (June 22, 2018)

Consolidation may happen because there is a different kind of planning that goes on in online courses. In a face to face course, SINQ faculty and graduate peer mentors often create their content as they are teaching and mentoring. In contrast, most of our participants spoke of designing their learning platform shell, curriculum, and activities, and instruction in the weeks before the course began. One SINQ faculty member explained how creating content was difficult during the course, when they said, "You can't really do that. I can't do that in an online class. I have to have it [the course] all figured out from the beginning" (Nob Hill, June 22, 2018). A graduate peer mentor explained,

Honestly, I think the hardest thing is just figuring out what kind of activities you are going to put together for that [online] class. Typically, by the time you know who your instructor is and have chatted with them enough and seen whatever kind of content might be in the course-it takes a while to go through assignments and figure out what you might introduce to help them. And then [you] have to plan for the term. (Lloyd, June 13, 2018)

Along with having content created, SINQ faculty and graduate peer mentors noted that they established clear norms through the first week of their course via co-creating group guidelines and establishing net-etiquettes. Mintu-Wimsatt, Kernek, and Lozada (2010) advocate integrating net-etiquette in faculty syllabi as a way to set clear guidelines and avoid future issues. While none of our participants noted that they put the net-etiquettes directly in their syllabi, most of them created activities and discussions to set those norms.

One SINQ faculty member explained how they believe setting norms in online courses can "standardize how people behave and help with some of the rudeness.... I think for digital natives, who are growing up where's it's always around them all the time, they have those inflections and that understanding of how that communication happens" (Pearl, June 22, 2018). A graduate peer mentor said, "In face to face, most people have ... social norms that we don't realize . . . but behind the screen, we can say whatever we want, I feel like" (Portsmouth, June 13, 2018). By codeveloping set norms with students, SINQ faculty and graduate peer mentors can create space for students to solve problems within their context collaboratively.

All of the SINQ faculty and graduate peer mentors believed it was important to apply their students lived experiences to their instruction. A SINQ faculty member explained it this way, "It is really important to use my students' own 
experiences in their own learning process. I think they have a lot of knowledge and experience that I don't even have that they can utilize in their own learning" (Belmont, June 18, 2018). A graduate peer mentor explained how to provide meaning to the assignment. Lloyd explains the course must have good content and offers an example of how to get people interested in the effects of food deserts.

I asked them to go to three different stores and take pictures of cheap food, things you might actually eat, and compare prices and that kind of stuff. Make a photo collage and post like two sentences about it. The interesting things, patterns that people saw and talked about, it's like "that was different than what happened over here where I live." And that actually made it interesting to them and gave them something to talk about, so as they approached the assignment they already had half of their paper written. (June 13, 2018)

When SINQ faculty and graduate peer mentors understand the social contexts that inform where students are coming from, regardless if it is online or in person, this knowledge can motivate them to shift their instruction. With this shift of instruction, SINQ faculty and graduate peer mentors can provide space for a collaborative approach that focuses on a social-cultural context and is situated in the student's lived experiences.

Not only is this collaborative approach vital working with students, but also vital in the SINQ faculty and graduate peer mentor relationships. In the next section, we describe the balance of SINQ faculty and graduate peer mentor working as a team.

\section{SINQ Faculty and Graduate Peer Mentors Relationships}

Creating a strong relationship between SINQ faculty and graduate peer mentoring is important, as well as challenging, with regard to communication, teaching style, and mentoring style. At Portsmouth, a graduate peer mentor explained that students suffer when there is a conflict between [SINQ] faculty and mentor. They said, "Whether something gets lost in translation or we don't communicate. . or, I won't get their teaching style and they won't get my mentoring style. At the end of the day, it's the students who suffer" (June 13, 2018). Williams, a SINQ faculty member, further explained this point when a faculty and mentor relationship is moved to an online context. They said, "Yeah. So, online is harder because you're not in person ... it really depends on the pairing. It's so much about the individuals involved. It's [the] relationship" (June 22, 2018). There are challenges to relationships, our participants also 
talked about how they strengthened their relationships by having frequent meetings to check in, having the same SINQ faculty or graduate peer mentor on a continuous basis, and having clear expectations and roles.

Graduate peer mentors explained that while in person they usually met on a weekly basis. In contrast, in an online class, this differed depending on the faculty. Richmond, a graduate peer mentor, said,

We don't meet like when I was mentoring in person. We were meeting every week. But that doesn't happen online. It's usually like at the beginning of the course.... And it's usually when we're at the end of the course they come back to me, and say you were more engaged than any other online mentor.

Lloyd, a graduate peer mentor, only corresponded with the teacher and never met in person. They said,

It is kind of funny in an online class. I think it depends on the professor. I didn't meet the last professor at all. We actually only communicated by email. She was also traveling doing some research ... she was traveling for research and stuff that she was doing for most of the term, and she wasn't even available for a face to face meeting before we started. But that's fine. (June 13, 2018)

In contrast, a SINQ faculty member said, "He [mentor] and I text and email and also have weekly voice meetings" (St. Johns, June 13, 2018). St. John continues,

Those [meetings] look like pretty similar to a mentor and instructor in-person meeting. Um, just all verbal (laughing). [We] go over the previous week and the upcoming week. We would have them on Sundays. We would reflect on the week that just passed. We would look forward to the week coming up. Talking about the course content, talking about students. Talking about students that needed additional support, students who might have needed more clarification on an assignment or clarification about the course material or theories we were looking at. And generally, a time to get on the same page and just connect with each other as two humans. (June 13, 2018)

Another SINQ faculty member, Belmont, explained meeting with mentors really varied:

It [meetings] really depends on the mentor. Some mentors, I've had multiple times. They kind of get in a rhythm [and] already know what's going 
to happen, so there's less contact. Other mentors need sort of a week to week check-in. Every week I check-in with my mentor even online or on email or in person, after class or in a separate meeting. (June 18, 2018)

Belmont said that they worked with mentors on multiple occasions. Most of the SINQ faculty and graduate peer mentors responded that having the same SINQ faculty member or mentor made a difference in the relationship. Williams, a SINQ faculty member, explains why it is important to have a mentor for consecutive terms,

So, online I've had a number of mentors. ... I had a mentor that I had a couple times, and then got permission to have her for an entire year to really do, like a structured, [and] focused [on] building a course that other people could use also. Because we had a really good working relationship. She was just amazing at setting up the mentor part of the classroom. She laid all this groundwork. Then subsequent mentors, I've had, they adjust what she did. (June 22, 2018)

A graduate peer mentor had a similar experience with their SINQ faculty member. They said,

I was able to get partnered with the same [SINQ] faculty member for the summer course. I was chatting with him because we had this great conv ersation early in spring about mentoring and synchronism activity. ... I was like listen, I want to do this. He didn't necessarily ask me to do it, I just thought it would be a good experience, especially to help bridge or cultivate that community sense for those students. (Clinton, June 22, 2018)

Belmont, a SINQ faculty also remarked about how they built a stronger relationship when they spent more terms together, when they said, "I had a mentor who was my mentor for a while and we actually [got to] know each other. I was actually her mentor. I felt [a] connection with her" (June 13, 2018).

Most of the comments of the SINQ faculty and the graduate peer mentors appeared to understand that both the SINQ faculty and the graduate peer mentor needed to be valued in order for their relationship to be successful. Pearl, a SINQ faculty member, seemed to sum up the understanding, when she said,

I think mentors have to feel valued. They have to feel part of the team, part of the collaboration. They have to feel like what they're doing matters, to themselves and to the students. And they have to feel valued by faculty that they work with. And on the faculty side, I think it's important 
that a mentor is invested in the process and really takes it seriously and has enthusiasm and develops good rapport with students. They [mentors] have to show that they're interested in the students, and that the students do well. (June 22, 2018)

Another SINQ faculty member, Nob Hill, really wanted to get to know the mentors, as well as how they can support them in the classroom and beyond, when they said, "Well, I try to find out what my mentor's goals are, for being a mentor [and] skill set. I don't want to ask them to do things that they don't, aren't within their skillset" (June 22, 2018).

While Nob Hill's effort to get to know the mentors and their skillset is laudable, some SINQ faculty and graduate peer mentor found challenging situations and opportunities in navigating their roles as instructor and mentor. For example, Richmond, a graduate peer mentor explained,

I think mostly what I have done is I've become a proxy for the instructor because some students come to me and say they could not get hold of the instructor despite repeated emails. You know if they have a question sometimes it's stuff related to citation styles or whatever, then I can give them opinions. (June 22, 2018)

Richmond continues, "But I think it's very important to be available. And the mentor can only do what the instructor tells you. You know our function is limited" (June 22, 2018).

Pearl, a SINQ faculty explained that accountability also fell on mentors. They described a similar situation where the mentor was unresponsive to emails and said, "At a certain point, I do stop trying as hard to deal with the mentor because I'm like ... you're wasting my time ... it's easier for me to just do it than to try to get you to do it" (June 22, 2018).

Similar to graduate peer mentor's comment about how they felt limited without direction from their SINQ faculty partner, Pearl continued and admitted that faculty members may be limited, too. Pearl wondered how much each faculty receives training to work with their mentor.

I have wondered, how much training they [instructors] get in terms of online stuff. I know that my training, well, I was not really trained in how to use mentors. But, for the face-to-face class, it's just easy to help students to work and do discussions, whatever the case might be. But I think I don't necessarily have the knowledge base to know how do I get this individual to do the work that they're supposed to be doing. (June 22, 2018) 
At the time of writing this, all undergraduate and graduate peer mentors are required to attend a four-day mentor training conference in the Fall that includes meeting with FRINQ and SINQ faculty, roles, and expectations. If mentors are assigned to teach an online course, they receive additional training to work online, as well as additional resources and support throughout theterm.

In contrast, before the term starts, the FRINQ and SINQ faculty member meets for one hour with their mentors. All faculty members do have opportunities to access our University's Office of Academic Innovation (OAI) for support, however many are unaware of the resources, choose not to, or do not have the time. One challenge for not only SINQ faculty but faculty as a whole is that at our University, "Adjunct [part-time] faculty teach $34 \%$ of the student credit hours, compared with $33 \%$ by full-time tenure track faculty and $28 \%$ full-time non-tenure track faculty" (Portland State University, 2018, para 1). Only two faculty member out of five who were interviewed were fixed term full-time faculty. The rest were Adjunct faculty, who most likely are holding other jobs, as well. Most Adjunct faculty do not receive training in instruction, regardless if it is online or in person, and often teach freshman and sophomore courses.

Despite these challenges, most of the SINQ faculty members have agreed with William's sentiment, when they said, "I tend to think of what I do [as] a collaboration. That's the perspective I bring. I want the mentor [to] feel like [that] they are a part of the process, but also understand that I don't overwhelm them" (June 22, 2018). In this collaboration, SINQ faculty and graduate peer mentors can also tackle together social justice issues that are encountered in an online context.

\section{SINQ Faculty and Graduate Peer Mentors Interrupting Oppressive Language and Behaviors}

This theme describes situations and experiences of SINQ faculty and online graduate peer mentors that encountered barriers and social justice issues in an online context. Most of our participants described challenging situations. Promoting engagement while also encouraging a baseline of critical thinking and challenging assumptions can be highly challenging in an online environment. It can be challenging because interactions can happen at any hour and in multiple places within the course, making it difficult for SINQ faculty to monitor

or possibly even to realize that oppressive or damaging conversations are going unmoderated. The oppressive language and actions could be seen as racist, sexist, homophobic, transphobic, ableist, sizeist, and overall, oppressive. This kind of hesitation is seen when one SINQ faculty member said:

And I felt concern a lot of the time because of the, at times, delicate content matter of the class. Someone would post something that the 
community would benefit from the instructor interrupting. I wouldn't be there in real time to be responsive and it would have impact. I want to be there. I don't know how you would get around that in an asynchronized online course, but [there was] harmful or offensive matter posted, and there were a couple of moments in the class where a student posted something expressing [their] religious views. [They] did so in a way that was in my eye hurtful. I was making sure that the class was protected and the student didn't feel shamed. (St. John, June 13, 2018)

The faculty member continued to explain the situation and used herself as a model in the discussion and perhaps offering critical hope. St. Johns said,

My response was using my own first hand [knowledge], using myself as an example. I used my own family as an example and said, we've got atheists and Buddhists, and Christians, and Mormons in my family. We've got a wide range, and we all practice our beliefs in very different ways, and some members of the same community might look at my brothers and sisters and parents and say you're not of this faith but I think that they have right to claim that. (June 13,2018 )

Additional participants echoed this concern indicating a fear of forgoing the interruption of microaggressions (Sue et al, 2007) and the challenge of addressing social justice issues in an online context. One SINQ faculty member described it as "kind of fraught" (Pearl, June 22, 2018). With the current political rhetoric and climate, regardless of a student's political persuasion, SINQ faculty and peer mentors can serve as a model for civil discourse in the classroom.

A graduate peer mentor also gave us an example of how to mediate a discussion that could have gone down a different path. Portsmouth said, online courses are "all about fostering community and not alienating people. Because I feel like we're at a liberal arts university and people have dissenting opinions for a reason and we have to try to figure out why" (June 13, 2018). In other words, Portsmouth is understanding the context of where a student's belief is coming from in order to inform their instruction.

One SINQ faculty member shared a situation that challenged the status quo and supported a student who self-identified as non-binary. Williams said,

I had a student who identified as non-binary, and was very frustrated because other students online kept referring to them as "a her," and multiple times they asked: "Can you please refer to me by my gender pronoun that I have said that I would like?" We [SINQ faculty and graduate peer mentor] went in administratively and adjusted so that it 
would reflect what their wishes were, and also asked people to do that. They [the student] felt supported by us, but they were frustrated about the process. We added language about that in our syllabus and our guides for being online, about being respectful of the gender pronouns. (June 22, 2018)

In this particular case, the SINQ faculty and graduate peer mentor could be exhibiting critical hope. The critical theory part is seen in both the SINQ faculty member, graduate peer mentor, and student are confronting the status quo of socially constructed gender differences. Whereas, the hope part is changing the situation for the student not only administratively, but also in how they instruct (e.g., change in syllabus).

In most cases, the examples of successful practice of interrupting oppressive dialogue were modeling by example, understanding the social context, and responding to student needs, as they evolved. Participants' candidness and selfreflections were important, as some disclosed they found themselves complicit in maintaining the status quo via remaining neutral or not knowing what to do. Participants also spoke about the ways that online learning offered students a space to frame and reframe where they are complicit in maintaining the status quo. Understanding where we are complicit and whose voices are absent and why is at the heart of critical hope. Far too often, underserved, vulnerable, disabled people, and community of color voices are muted in academia because of institutional "white cultural norms" that continue to set the tone (Richards, 2018, para. 5).

\section{Discussion}

Our last theme is online strategies. We have created a practical list of pedagogical practices that our participants deemed as successful. While the practices in this list are not proven empirically, they have worked for the participants who mentioned them and may be useful to attempt or to modify or, to inspire other thoughts and ideas about online pedagogy.

Due to the small sample size $(n=9)$, and out of respect and acknowledgment of the diversity of experience and teaching of SINQ faculty and graduate peer mentors, we cannot generalize. Nevertheless, we believe that some of these ideas, concepts, and techniques can be transferable (Morgan, 2007). In other words, SINQ faculty and graduate peer mentors use them in other online settings and adapt them to fit the curriculum and instruction of their particular course, as well as being culturally responsive to their students. Please see Table 1 for effective practices in online pedagogy. 


\section{Course Design}

- Take advantage of campus support for course design;

- Set up an optional community discussion board;

- Create videos or screen casts for students;

- Use students' own experience in their learning process (e.g., plan an assignment where students go into their neighborhoods to do research);

- Organize the learning platform shell where it is user-friendly;

- Design courses so students are working towards one project the whole term;

- Assign students to online course "buddies" to keep each other accountable;

- Engage students in both small group and large group discussions;

- Create downloadable PDFs for students;

- Build ePortfolios and have students give one another feedback on those e-portfolios.

\section{First Week}

- Students who have not shown up in the first week of the course;

- Require students to complete a survey that orients them to online courses and discovers what resources they need and respond individually with tailored resources;

- Ask students for their names and pronouns;

- Set guidelines for online communication (i.e., netiquette);

- Ask students to email questions, then post a Q\&A with most common questions to the group

\section{Throughout Quarter}

- Have online discussions be meaningful and goal oriented;

- Reach out to students who do not participate in discussions;

- When text communication is not working, meet in person or using asynchronous technology like phone or video chat;

- Participate in student discussions;

- Virtual office hours (instructor available by phone, IM, or email) for students;

- Conduct individual phone conferences with students;

- Use online chat tools such as Slack;

- Interrupt oppression or microaggressions when they occur in students discussions;

- Email students who are not engaged and offer resources;

- Have students share and respond to voice recordings;

- Ask students to post videos and respond with videos;

- Respond to student emails quickly;

- Be available for face-to-face meetings with students in person or over video chat. 
Although sustaining online culture can be challenging, our participants have offered some technology strategies. For example, some participants commented that online teaching provides a richer and more diverse experience for the students to express themselves and delve deeper into their subject areas using technological tools not often used in traditional classrooms. Please see Table 2 for platforms that SINQ faculty and graduate peer mentors apply when they are teaching and mentoring an online course.

Standard tools, including video, audio, text, and graphics, can support better communication in the online classroom. Participants often used various forms of technology to help bridge the gap between face-to-face and online lessons, especially video. Overall, SINQ faculty and peer mentors found that technology was essential to build communities and created an innovative space for pedagogy, curriculum, and instruction.

Even though our sample size was small, we hope that our research can be useful to other SINQ faculty and graduate peer mentors who practice in an online setting.

Table 2 | Platforms that SINQ faculty and graduate peer mentors apply when they are teaching and mentoring an online course

\begin{tabular}{|c|c|c|}
\hline $\begin{array}{l}\text { Platforms } \\
\text { (Cloud-Based) }\end{array}$ & $\begin{array}{l}\text { Platforms } \\
\text { (Communication) }\end{array}$ & $\begin{array}{l}\text { Platforms } \\
\text { (Presentations) }\end{array}$ \\
\hline $\begin{array}{l}\text { Desire to Learn } \\
(\mathrm{D} 2 \mathrm{~L}) \\
\text { www.d2l.com/ } \\
\text { Kaltura } \\
\text { MediaSpace } \\
\text { www.corp.kaltura.com } \\
\text { Google Drive } \\
\text { www.google.com/drive } \\
\text { Wikispaces } \\
\text { www.wikispaces.com }\end{array}$ & $\begin{array}{l}\text { Google Hangouts } \\
\text { www.hangouts.google.com } \\
\text { Skype } \\
\text { www.skype.com } \\
\text { Flipgrid } \\
\text { www.flipgrid.com } \\
\text { VoiceThread } \\
\text { www.voicethread.com } \\
\text { Slack } \\
\text { www.slack.com } \\
\text { GitHub } \\
\text { www.github.com } \\
\text { Zoom } \\
\text { www.zoom.us }\end{array}$ & $\begin{array}{l}\text { PowerPoint Google Slides } \\
\text { www.google.com/slides } \\
\text { QuickTime (Screen Cast) } \\
\text { www.apple.com/quicktime } \\
\text { VideoScribe } \\
\text { www.videoscribe.co/en } \\
\text { Prezi } \\
\text { www.prezi.com }\end{array}$ \\
\hline
\end{tabular}




\section{Limitations}

We see our study as a way to explore how online SINQ faculty and graduate peer mentors communicate and cultivate connections with students and communities while delivering an online course. Since our participant pool includes only SINQ faculty and peer mentors, we are missing the voices of students. Students maintain a valuable perspective on the efficacy of our courses and are likely the best measure of our success. We chose to focus on faculty and graduate peer mentors because we were aware of a great deal of research that focused on online students (Cole, Shelley, Swartz, 2014). However, having included students in our research-along with SINQ faculty and graduate peer mentorsour research may have contributed to a fuller understanding of the shortfalls and successes of online learning.

In addition to the participant pool, many of our SINQ faculty and graduate peer mentors who were interviewed also had the experience of teaching University Studies courses face-to-face before they transitioned to online. Many SINQ faculty and peer mentors have seen how dialogue in real time contributes to an integrated dialectic among students whose identities and dispositions intersect with their realities and the realities of others. In light of that, more attention should be given to the student's lived experience so that it can be understood and appreciated in asynchronous learning environments, which is in line with our conceptual framework-critical hope.

\section{Conclusion}

We explored how online SINQ faculty and graduate peer mentors instruct, build relationships, and interrupt oppressive moments while delivering an online course. We encountered a wide array of curriculum and instruction practices used by SINQ faculty and graduate peer mentors. Through semistructured interviews and the application of critical hope, we offered four themes which were online instruction, SINQ faculty and graduate peer mentor relationships, interrupting oppressive language and behaviors, and online strategies. Due to University Studies' unique dedication to integrative, whole student learning and engaged practices and its programmatic support for and research on effective teaching practices, our classrooms are not only hubs of learning but rich with opportunities to learn from faculty and undergraduate and graduate mentors.

STACI B. MARTIN, EdD, is a faculty member in the School of Social Work (SSW). Dr. Martin's research and teaching interest include critical hope and critical despair, refugee education, social-emotional learning, participants as co-researchers, and community-based action research. 
MEREDITH E. MICHAUD, EdD, works with University Studies to provide training, resources, and support to mentors. Dr. Michaud mentored for three years while earning her doctorate in educational leadership at Portland State, and is interested in exploring how online mentors and faculty can support students in online courses.

CHRISTIAN D. LOGERSTEDT, MSW, is a social worker and graduate of Portland State University's MSW program who served as a peer and graduate mentor for four years while completing his Bachelor and Master's degrees. He is interested in ways interdisciplinary critical education can facilitate the development of dynamic citizens, tactful communicators, and compassionate neighbors.

\section{WORKS CITED}

Albright, J., Hurd, N., \& Hussain, S. (2017). Applying a social justice lens to youth mentoring: A Review of the literature and recommendations for practice. American Journal of Community Psychology, 59(3-4), 363-81.

Brinkmann S. (2014). Interview. In T. Teo (Ed.) Encyclopedia of Critical Psychology. New York: Springer.

Budge, S. (2006). Peer mentoring in postsecondary education: Implications for research and practice. Journal of College Reading and Learning, 37(1), 71-85.

Cole, M., Shelley, D., \& Swartz, L. (2014). Online instruction, e-learning, and student satisfaction: A three-year study. International Review of Research in Open and Distributed Learning, 15(6), $111-31$.

Collier, P. J. (2017). Why peer mentoring is an effective approach for promoting college student success. Metropolitan Universities, 28(3), 9-19.

Colvin, J., \& Ashman, M. (2010). Roles, risks, and benefits of peer mentoring relationships in higher education. Mentoring \& Tutoring: Partnership in Learning, 18(2), 121-34.

Crisp, G. \& Cruz, I. (2009). Mentoring college students: A critical review of the literature between 1990 and 2007, Review of Educational Research, 50, 525-45. doi.org/10.1007/s11162-009-9130-2.

DuBois, D. (2014). Handbook of youth mentoring / (Vol. 2). Thousand Oaks, CA: Sage Publications.

Freire, P. (2000). Pedagogy of the oppressed (30 ${ }^{\text {th }}$ Anniversary ed.). New York: Continuum.

- . (1994). Pedagogy of hope: Reliving pedagogy of the oppressed. London, UK: Bloomsbury.

Fylan, F. (2005). Chapter 6: Semi-structured interviews. In J. Miles, \& P. Gilbert (Eds). A handbook of research methods for clinical and health psychology. New York: Oxford University Press.

James, L. R., Demaree, R. G., \& Wolf, G. (1984). Estimating within-group interrater reliability with and without response bias. Journal of Applied Psychology, 69(1), 85-98. http://dx.doi.org/10.1037/0021-9010.69.1.85.

Martin, S. B., Warsame, D., Bigirimana, C., Lajustine, V., Teferra, G., Abdi, A., \& Taban, J. (2018 September). Kakuma Refugee Camp: Where knowledge and hope reside. In P. Blessinger and E. Sengupta (Eds.), Innovations in Higher Education Teaching and Learning (IHETL): Refugee Education: Integration and Acceptance of Refugees in Mainstream Society. Somerville, MA: Emerald Group Publishing.

Mintu-Wimsatt, A., Kernek, C., \& Lozada, H. R. (2010 March). Netiquette: Make it part of your syllabus. MERLOT Journal of Online Learning and Teaching, 6(1), 264-67. 
Mitchell, Tania D. (2008). Traditional vs. critical service-learning: Engaging the literature to differentiate two models. Michigan Journal of Community Service Learning, 14(2), 50-65.

Morgan, D. L. (2007). Paradigms lost and pragmatism regained: Methodological implications of combining qualitative and quantitative methods. Journal of Mixed Methods Research, 1(1), 48-76.

Portland State University. (2018). Adjunct resources. Retrieved from https://www.pdx.edu/hr/adjunctresources.

Richards, B. D. (2018 May 25). Is your university racist? Inside Higher Ed. Retrieved from https://www.insidehighered.com/advice/2018/05/25/questions-institutions-should-askthemselves-determine-if-they-are-operating.

Saldaña, J. (2015). Thinking qualitatively: Methods of mind. Thousand Oaks, CA: Sage.

Sue, D. W., Capodilupo, C. M., Torino, G. C., Bucceri, J. M., Holder, A. M. B., Nadal, K. L., \& Esquilin, M. (2007). Racial microaggressions in everyday life: Implications for clinical practice. American Psychologist, 62(4), 271-86.

Washington, R., \& Cox, E. (2016). How an evolution view of workplace mentoring relationships helps avoid negative experiences: The developmental relationship mentoring model in action. Mentoring \& Tutoring, 24(4), 318-40. 